\title{
GROWTH RESPONSES OF HOT CHILLI (Capsicum chinense JACQ.) TO ELEVATED CARBON DIOXIDE AND TEMPERATURE
}

\author{
Department of Crop Physiology, Assam Agricultural University, Jorhat-785013, Assam \\ Received - February 21, 2020; Revision - June 26, 2020; Accepted - August 24, 2020 \\ Available Online - August 25, 2020 \\ DOI: http://dx.doi.org/10.18006/2020.8(4).434.440
}

Sangita Das, Ranjan Das*, Prakash Kalita, Ujjal Baruah

KEYWORDS
CTGT
Capsicum chinense Jacq.
Leaf area index
Leaf area duration
Specific leaf weight
Root: Shoot

\begin{abstract}
The current study was carried out to evaluate the response of hot chilli (Capsicum chinense Jacq.) to elevated $\mathrm{CO}_{2}$ and temperature for two consecutive years by using CTGT (Carbon dioxide Temperature Gradient Tunnel) technology at Assam Agricultural University, Jorhat. Hot chilli plants were grown at different conditions viz. ambient (open condition); CTGT I (380 ppm $\mathrm{CO}_{2}$ and ambient temperature); CTGT II (550 ppm $\mathrm{CO}_{2}+2^{\circ} \mathrm{C}$ temperature elevation from CTGT I) and CTGT III (750 ppm $\mathrm{CO}_{2}+4^{\circ} \mathrm{C}$ elevation from CTGT I). Results of the study revealed that plants grown at CTGT II and CTGT III recorded a significant increase in root: shoot ratio, leaf area index (LAI), leaf area duration (LAD) in both the year of experimentation. An increase in specific leaf weight (SLW) and a decrease in specific leaf area (SLA) was observed due to the elevation of $\mathrm{CO}_{2}$ and temperature at CTGT II. A highly significant positive correlation $(r=0.997)$ was obtained between SLW and LAI. Further, LAD showed a significant positive correlation $(r=0.968)$ to fruit yield per plant. Regression analysis revealed $79.1 \%$ contribution of LAD to the fruit yield. Amongst the two cultivars ( cv. Manipur and cv. Assam), cv. Manipur performed better in terms of morphological and growth parameters under elevated carbon dioxide and temperature conditions. This indicates the differential responses of hot chilli genotypes under future climate change conditions. Thus, the current study documented that elevated $\mathrm{CO}_{2} @ 550 \mathrm{ppm}$ and $2^{\circ} \mathrm{C}$ temperature may favor the production of Bhut Jolokia due to enhanced assimilation of $\mathrm{CO}_{2}$.
\end{abstract}

* Corresponding author

E-mail: rdassam1966@gmail.com (Ranjan Das)

Peer review under responsibility of Journal of Experimental Biology and Agricultural Sciences.

Production and Hosting by Horizon Publisher India [HPI] (http://www.horizonpublisherindia.in/).

All rights reserved.
All the articles published by Journal of Experimental Biology and Agricultural Sciences are licensed under a Creative Commons Attribution-NonCommercial 4.0 International License Based on a work at www.jebas.org.

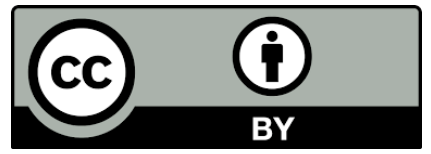




\section{Introduction}

Carbon dioxide is a potent greenhouse gas that plays a vital role in regulating the earth's surface temperature through the greenhouse effect (Petty, 2004). High $\mathrm{CO}_{2}$ concentrations, plus water vapor would increase the global mean surface temperature by $3-5^{\circ} \mathrm{C}$ in 2100 (IPCC, 2014). With the beginning of the industrial era, a rise of $100 \mu \mathrm{mol} \mathrm{mol}^{-1} \mathrm{CO}_{2}$ has been recorded and it has been predicted that the rise in the rate will be approximately $2 \mu \mathrm{mol} \mathrm{mol}^{-1}$ per year. Due to this, warming of more than $6^{\circ} \mathrm{C}$ is expected in the $21^{\mathrm{st}}$ century under some scenarios. The increase in temperature is related to elevation in $\mathrm{CO}_{2}$ (ACIA, 2004; Solomon et al., 2007). In the global climate change situation, the associated elevation in the temperature is a significant abiotic stress. A change in carbon dioxide concentration in the atmosphere might have a significant effect on photosynthesis (Van der Kooi, 2016).

The crop used in the current study was hot chilli or bhut jolokia or king chilli (Capsicum chinense Jacq.), which is an important medicinal and spice crop (Rudrapal \& Sarwa, 2020). India is the biggest producer and exporter of chilli and annually India produced around 35000 tons of chilies worth Rs. 80 corer in every year (Tiwari et al., 2005). The NE region of India has a unique high humidity environment and is considered a 'hot spot' of biodiversity. It has given rise to the world's hottest chilli, 'Bhut Jolokia' (Guinness Book of World Records, 2006). Capsicum plant growth depends on the soil temperature and it ranges from $20-22^{\circ} \mathrm{C}$. Moreover, a night temperature of $18-27^{\circ} \mathrm{C}$ is crucial for its fruit development (Purkayastha et al., 2012). The reproductive stage is more sensitive to heat stress, causing impaired fertilization, as a result, abortion of flowers occur (Bhattacharya, 2019). Similar to bell pepper, bhut jolokia is very much sensitive to high temperature and reduced fruit set with an increase in temperature (Erickson \& Markhart, 2002) which leads to lower yield and less return. Thus it is important to study the interactive effect of the elevated $\mathrm{CO}_{2}$ and high-temperature stress, on the morphology and growth parameters of Capsicum species collected from Assam and Manipur in the present investigation and to identify a suitable cultivar for growing under the present scenario of climate change.

\section{Materials and Methods}

\subsection{Experimental Setup}

The study was conducted under field and Carbon dioxide Temperature Gradient Tunnels (CTGTs) at Assam Agricultural University, Jorhat, Assam from 2012 to 2014. Two locally grown genotypes of Capsicum chinense Jacq. were collected from Manipur (viz. cv 1) and Assam (viz. cv 2) for studying the effect of high carbondioxide and temperature on various morphological and growth parameters. Four different treatments i.e. Field
(Ambient $\mathrm{CO}_{2}$ condition and temperature condition); CTGT I (380 ppm CO $2+$ ambient temperature); CTGT II (550 ppm CO $\mathrm{CO}_{2}+$ $2^{\circ} \mathrm{C}$ higher than ambient) and CTGT III (750 ppm $\mathrm{CO}_{2}+4^{\circ} \mathrm{C}$ higher than ambient) were given to Capsicum plants. CTGT I was treated as a control. The carbon dioxide was maintained throughout the entire crop growth period from 9 a.m. to 2 p.m. regularly. At CTGT II and CTGT III, a temperature elevation of $2^{\circ} \mathrm{C}$ and $4^{\circ} \mathrm{C}$ was imposed from flower bud initiation up to maturity. The elevated temperature was provided by the InfraRed Gas Analyzer which was regulated by SCADA software. The carbon dioxide temperature gradient tunnel (CTGT), (Make: Genesis Technologies, Maharashtra, India) was used for creating a controlled environment for the experiment. The CTGTs were covered by poly carbonated sheet of 100 -micron gauge showing greater than $85 \%$ light transmission. Recording of data viz. temperature, relative humidity in CTGTs, and ambient conditions were done by using temperature sensors, humidity transmitters etc. $\mathrm{CO}_{2}$ gas cylinders supplied the $\mathrm{CO}_{2}$ gas. The entire system was automated to obtain the desired $\mathrm{CO}_{2}$ level. The monitoring and controlling of $\mathrm{CO}_{2}$ levels in all the chambers were done by Datalogger, SCADA software, and PC.

Capsicum seeds, previously treated with Captan @ 2.5g/Kg were germinated. Earthen pots were filled with fertilized soil @ 120: 60: $60:: \mathrm{N}: \mathrm{P}: \mathrm{K} \mathrm{kg} / \mathrm{ha}$. In each treatment, five pots were kept per cultivar. The experimental design was CRD with factorial treatment combination and data were collected during the flowering stage. The experiment was repeated next year and data were analyzed.

\subsection{Parameters recorded}

\subsubsection{Leaf area Index}

For calculation of leaf area index, the leaf area was measured using a portable leaf area meter (model LI 3000). LAI was calculated using the method of Evans (1972) using the following formula.

$$
L A I=\frac{\text { Total leaf area }}{\text { Ground area }}
$$

\subsubsection{Leaf area duration}

For calculating LAD, the LAI was calculated twice at an interval of 15 days and was expressed in days. LAD was calculated using the method of Power et al. (1967) using the following formula

$$
\mathrm{LAD}=\frac{\mathrm{L}_{1}+\mathrm{L}_{2}}{2} \mathrm{X}\left(\mathrm{t}_{2}-\mathrm{t}_{1}\right)
$$

Where, $\mathrm{L}_{1}=\mathrm{LAI}$ at the first stage; $\mathrm{L}_{2}=\mathrm{LAI}$ at the second stage; $\left(t_{2}-t_{1}\right)=$ Time interval in days 


\subsubsection{Root: shoot ratio}

Roots were dug out by the method of Sirohi et al. (1978). Roots were washed gently to separate soils from the roots. The ratio of root growth to the top growth was expressed by root: shoot ratio.

\subsubsection{Specific leaf area (SLA)}

The specific leaf area (SLA) was calculated according to the method of Das (2003). The specific leaf area was calculated as leaf area per unit of dry matter and was expressed as $\mathrm{cm}^{2} \mathrm{~g}^{-1}$. The following formula was used for calculating Specific leaf area

$$
\mathbf{S L A}=\left\{\left(\mathbf{A}_{\mathbf{2}} / \mathbf{L W}_{\mathbf{2}}\right)+\left(\mathbf{A}_{\mathbf{1}} / \mathbf{L W}_{\mathbf{1}}\right) / 2\right.
$$

Where $A_{1}$ and $A_{2}$ were leaf area and $L W_{1}$ and $L W_{2}$ were the dry weight of leaf for time $t_{1}$ and $t_{2}$ respectively.

\subsubsection{Specific leaf weight (SLW)}

Specific leaf weight (SLW) was calculated according to the method of Das (2003). Specific leaf weight denoted leaf dry weight per unit leaf area and was expressed as $\mathrm{g} \mathrm{cm}^{-2}$. Specific leaf weight was calculated using the following formula.

$$
\mathbf{S L W}=\left\{\left(\mathbf{L W}_{\mathbf{2}} / \mathbf{A}_{\mathbf{2}}\right)+\left(\mathrm{LW}_{\mathbf{1}} / \mathbf{A}_{\mathbf{1}}\right) / 2\right.
$$

Where $A_{1}$ and $A_{2}$ were leaf area and $L W_{1}$ and $L W_{2}$ were the dry weight of leaf for time $t_{1}$ and $t_{2}$ respectively.

\subsubsection{Yield Parameter}

Mature and ripe fruits were harvested at the time interval and fresh weights were calculated. At the end of the crop period, the total fruit yield/ plant was calculated and expressed as g plant ${ }^{-1}$.

\section{Results and Discussion}

A significant difference in LAI was noted among the tested cultivars. An increase in LAI ( $7 \%$ and $11 \%$ ) was recorded in cv.

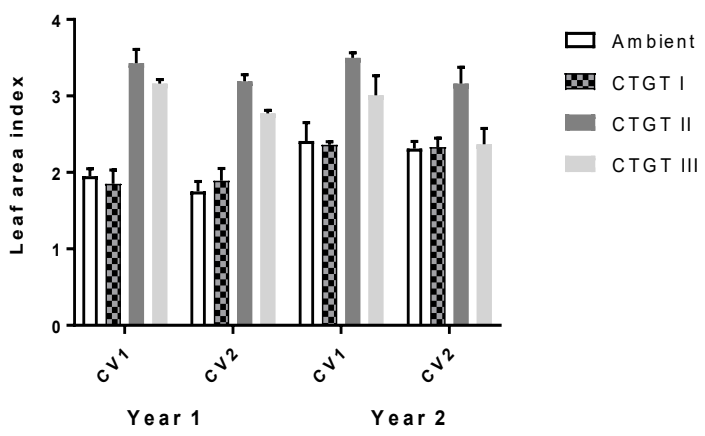

Figure 1 Interactive effect of elevated carbon dioxide and temperature on leaf area index in $C$. chinense
Manipur over cv. Assam in the first and second year respectively. Elevated $\mathrm{CO}_{2}$ and temperature brought an increase of $56 \%$ and $74 \%$ in CTGT III and CTGT II treatment respectively over the ambient condition in the first year. In the second year of the experiment, an increase of $14 \%$ and $42 \%$ was reported in CTGT III and CTGT II respectively (Figure 1). A significant difference in LAD was recorded amongst the genotypes. Chilli cultivar cv. Manipur has 16 and $17 \%$ higher LAD in the first and second year respectively (Figure 2). A significant difference in LAD was also recorded amongst the treatments and cultivars. Further, $\mathrm{CO}_{2}$ enrichment enhanced the LAI and LAD in the selected cultivars. As compared to CTGT II, a reduction in these growth parameters was observed at CTGT III.

In the current study, the effect of high temperature at CTGT II and CTGT III could be ameliorated due to the $\mathrm{CO}_{2}$ elevation. As evidenced by the present study, the enhanced LAI and LAD could maintain the photosynthesizing capacity for a longer period. Hence the newly produced leaves and branches at CTGT II might have acted as a temporary sink for utilizing the photoassimilates. Such leaves acted as a source of assimilation for reproductive organs; the ultimate sink for utilizing the photoassimilates. Thus the demand for photoassimilates by the fruit might have been catered by the photosynthates in both the cultivars. Thus the process of feedback inhibition might have been eliminated due to elevated $\mathrm{CO}_{2}$. High temperatures can cause loss of cell water content, cell size, and eventually reduced growth. Such a reduction in growth due to elevated temperature has been observed in maize and pearl millet (Ashraf \& Hafeez., 2004).

The current study showed a significant increase in the specific leaf weight (SLW) and decreased the specific leaf area due to $\mathrm{CO}_{2}$ elevation. Similar findings were reported by Mailliard et al. (2001), those who have reported a decrease in specific leaf area under elevated $\mathrm{CO}_{2}$. The primary photosynthetic organelle in the plants which influences the plants' growth and development are the chloroplasts (Sharma et al., 2014). Chinese Yam grown under

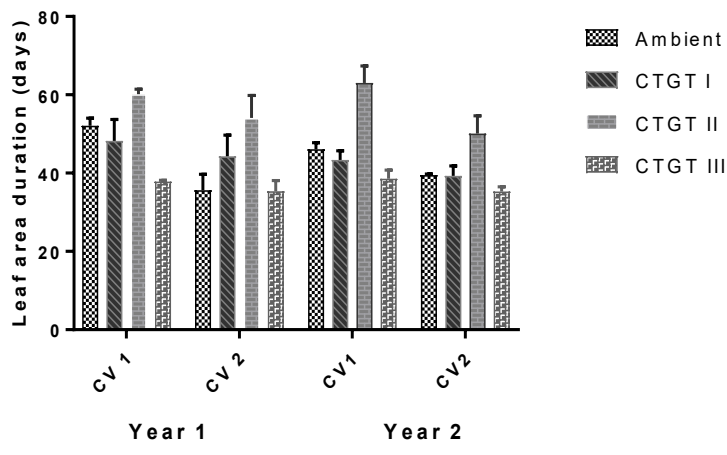

Figure 2 Interactive effect of elevated carbon dioxide and temperature on leaf area duration in C. chinense

Journal of Experimental Biology and Agricultural Sciences http://www.jebas.org 
elevated $\mathrm{CO}_{2}$ showed thicker palisade layer than those grown under ambient conditions resulting in a thicker leaf blade (Thinh et al., 2018). Moreover, Teng et al. (2006) reported an increase in the number of chloroplasts per mesophyll cell in leaves of $A$. thaliana when grown under elevated $\mathrm{CO}_{2}$. According to them the increase in SLW, may be due to anticlinal divisions of mesophyll cells. Thus additional palisade layers were produced which were the resource utilization sites for higher $\mathrm{CO}_{2}$. In Capsicum species too, a marked increase in specific leaf weight was recorded. At CTGT III, the high-temperature stress significantly decreased the SLW as compared to CTGT II. Bray \& Reid (2002) also reported an increase in leaf area, LAI, LAD, SLW in Phaseolus $s p$. when grown under elevated $\mathrm{CO}_{2}$ concentration. While Jumrani et al. (2017) reported that an elevation in temperature brought a negative effect on SLW and leaf thickness in soybean.

The current study showed an increase in leaf area duration at CTGT II. This indicated that the plants grown at CTGT II conditions got more time for the production of photosynthates, which was ultimately used for fruit development. Canopy assimilation and plant growth are affected by LAI when grown under elevated $\mathrm{CO}_{2}$ ( $\mathrm{Li}$ et al., 2018). In an ecosystem modeling study from 1981 to 2016, the increase in LAI accounted for $12.4 \%$ of the accumulated terrestrial carbon sink (Chen et al., 2019). Whereas in a study on some forest species indicated that LAI was not affected by the elevation of $\mathrm{CO}_{2}$ levels, but $\mathrm{CO}_{2}$ enrichment could stimulate leaf-area expansion in field experiments in some other ecosystems Leaf expansion of Populus was sensitive to atmospheric carbon dioxide (Ferris et al., 2001). In the birch forest, an increase in $\mathrm{CO}_{2}$ and $\mathrm{O}_{3}$ caused a $40 \%$ increase above ambient values which affected tree water use. The 1 sap flux was not affected by elevated [O3], but an increase of $18 \%$ was recorded by elevated $\left[\mathrm{CO}_{2}\right]$ and $\mathrm{O}_{3}$ regimes (Uddling et al., 2008).

A significant difference in SLA and SLW was recorded amongst the cultivars and treatments for both the years (Table 1). Correlation studies between LAD and yield revealed a significant positive $r$ value $(r=0.968)$ which indicates that LAD and yield/ plant are highly associated with one another in a linear way (Table 2). The SLW showed a negative correlation $(\mathrm{r}=-0.996)$ with SLA. A highly significant positive correlation $(r=0.997)$ between SLW and LAI was obtained from the data analyzed.

Table 1 Interactive effect of elevated carbon dioxide and high temperature on specific leaf area and specific leaf weight in $C$. chinense

\begin{tabular}{|c|c|c|c|c|c|c|c|c|}
\hline \multirow{2}{*}{ Treatments } & \multicolumn{4}{|c|}{ Specific leaf area $\left(\mathrm{cm}^{2} \mathrm{~g}^{-1}\right)$} & \multicolumn{4}{|c|}{ Specific leaf weight $\left(\mathrm{g} \mathrm{cm}^{-2)}\right.$} \\
\hline & \multicolumn{2}{|c|}{$1^{\text {st }}$ year } & \multicolumn{2}{|c|}{$2^{\text {nd }}$ year } & \multicolumn{2}{|c|}{$1^{\text {st }}$ year } & \multicolumn{2}{|c|}{$2^{\text {nd }}$ year } \\
\hline Field & \multicolumn{2}{|c|}{338.16} & \multicolumn{2}{|c|}{310.4} & \multicolumn{2}{|c|}{0.0031} & \multicolumn{2}{|c|}{0.0033} \\
\hline CTGT-I & \multicolumn{2}{|c|}{323.74} & \multicolumn{2}{|c|}{340.22} & \multicolumn{2}{|c|}{0.0030} & \multicolumn{2}{|c|}{0.0031} \\
\hline CTGT-II & \multicolumn{2}{|l|}{259.30} & \multicolumn{2}{|c|}{246.01} & \multicolumn{2}{|c|}{0.0039} & \multicolumn{2}{|c|}{0.0041} \\
\hline CTGT-III & \multicolumn{2}{|l|}{268.14} & \multicolumn{2}{|c|}{283.45} & \multicolumn{2}{|c|}{0.0037} & \multicolumn{2}{|c|}{0.0037} \\
\hline SEd & \multicolumn{2}{|l|}{6.47} & \multicolumn{2}{|c|}{9.97} & \multicolumn{2}{|c|}{0.00003} & \multicolumn{2}{|c|}{0.015} \\
\hline$P(0.05 \%)$ & \multicolumn{2}{|l|}{14.29} & \multicolumn{2}{|c|}{2.13} & \multicolumn{2}{|c|}{0.000065} & \multicolumn{2}{|c|}{0.032} \\
\hline cv. Manipur & \multicolumn{2}{|l|}{283.88} & \multicolumn{2}{|c|}{284.03} & \multicolumn{2}{|c|}{0.0036} & 0.00 & \\
\hline cv. Assam & 310.80 & & & & & & 0.00 & \\
\hline SEd & 4.57 & & & & 0.0 & & 0.00 & \\
\hline$P(0.05 \%)$ & 10.11 & & & & & & 0.00 & \\
\hline & & & & atment $\mathrm{X} \mathrm{Cu}$ & & & & \\
\hline & $1^{\text {st }}$ year & & & & & & $2^{\text {nd }} y$ & \\
\hline Titatintits & cv. Manipur & cv. Assam & cv. Manipur & cv. Assam & cv. Manipur & cv. Assam & cv. Manipur & cv. Assam \\
\hline Field & 311.87 & 364.46 & 291.86 & 328.93 & 0.0032 & 0.0027 & 0.0035 & 0.0031 \\
\hline CTGT-I & 310.99 & 336.49 & 321.76 & 358.68 & 0.0032 & 0.0029 & 0.0031 & 0.003 \\
\hline CTGT-II & 250.81 & 267.8 & 245.45 & 246.57 & 0.0040 & 0.0037 & 0.0041 & 0.0041 \\
\hline CTGT-III & 261.84 & 274.45 & 277.04 & & 0.0038 & 0.0037 & 0.0038 & 0.0036 \\
\hline SEd & 9.15 & & & & & & 0.00 & \\
\hline$P(0.05 \%)$ & 20.13 & & & & & & 0.00 & \\
\hline
\end{tabular}

Journal of Experimental Biology and Agricultural Sciences http://www.jebas.org 
Table 2 Correlation study of some growth parameters in C. chinense

\begin{tabular}{|ccccc|}
\hline Parameters & Leaf area index & Specific leaf area & Specific leaf weight & Leaf Area Duration \\
\hline Yield & 0.715 & -0.651 & 0.664 & $0.968^{*}$ \\
\hline Leaf area index & & -0.991 & $0.997^{* *}$ & 0.542 \\
\hline Specific leaf area & & -0.996 & -0.454 \\
\hline Specific leaf weight & & & 0.479 \\
\hline
\end{tabular}

* Significance at $5 \%$ level; ** Significance at $1 \%$ level

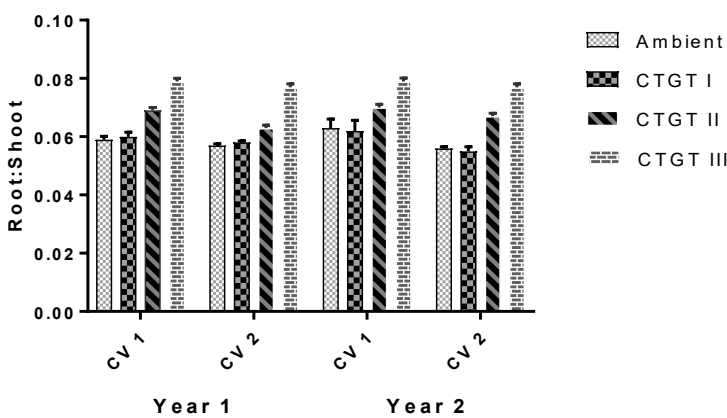

Figure 3 Interactive effect of elevated carbon dioxide and temperature on root: shoot ratio in C. chinense

Results of two years data revealed a significant difference in root: shoot ratio between the cultivars while interaction effect was reported between the treatments and cultivars for both the years of experimentation (Figure 3). A significantly higher root: shoot ratio was observed in CTGT II and CTGT III for both the years. Among the tested cultivars, cv. Manipur recorded a significantly higher root: shoot over cv. Assam for both the years of experimentation. A significantly higher root: shoot ratio ranging from 0.66 to 0.78 and 0.68 to 0.78 was reported for the treatment CTGT II and CTGT III for the first and second year respectively.

Elevated $\mathrm{CO}_{2}$ enhanced the growth of root and shoot which resulted in higher root: shoot ratio (Liu et al., 2002). In the present study, the elevated $\mathrm{CO}_{2}$ helped in sequestration of carbon by the capsicum plants and this resulted in higher root: shoot ratio probably due to more root growth in terms of root volume and secondary root number. The allocation of biomass in plant parts plays an important role in the adaptation of stress conditions (Ge et al., 2012). The current study depicts the enhanced rate of root growth as compared to shoot under elevated $\mathrm{CO}_{2}$. The better root growth might have facilitated the uptake of nutrients and water for supporting plant growth and adaptation under high temperatures. Similarly, Arnone et al. (2000) reported that crop grown under elevated $\mathrm{CO}_{2}$ will have a larger and highly branched root system which would increase the capacity for resource acquisition. Similarly, as compared to plants with a smaller and fibrous root system, tuberous and woody root system tends to respond more to elevated $\mathrm{CO}_{2}$ (Runion et al., 2010).

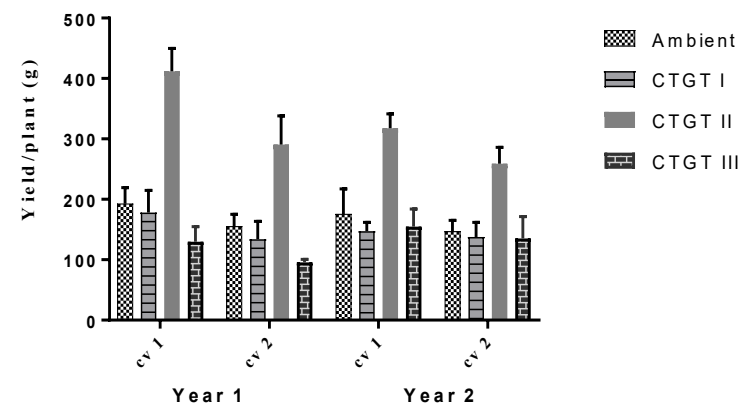

Figure 4 Interactive effect of elevated carbon dioxide and temperature on fruit yiels/plant in C. chinense

In the yield/plant, a significant difference was noted amongst the different treatments and amongst the cultivars. CTGT II recorded significantly higher yield/ plant as compared to CTGT III and ambient conditions (Figure 4). Similarly, cv. Manipur recorded a significantly higher yield/ plant as compared to cv. Assam.

In the current study, the crop $C$. chinense is an indeterminate type of plant, hence flower and fruit development took place for a longer growth period. This was evident from higher LAI and LAD. The potentiality of the crop to experience higher leaf area duration with a higher rate of photosynthesis has to lead better yield. The increased LAD along with the indeterminate growth pattern resulted in greater productivity under the CTGT II. The contribution of leaf area duration to the fruit yield has also been estimated and results have been presented in Figure 5. The coefficient of estimated regression is 0.791 level. The computed $\mathrm{R}^{2}$ value indicates that 79.1 percent of the total yield being attributed to leaf area duration.

From the present study, it can be concluded that under the present scenario of climate change, the elevation of climatic factors viz. $\mathrm{CO}_{2}(550 \mathrm{ppm})$ and temperature $\left(2^{\circ} \mathrm{C}\right)$ is beneficial for higher production of hot chilli crop under farmers' field. Cultivar Manipur could resist the high carbon dioxide and temperature stress, thereby indicating its adaptability for growing in the future years. 


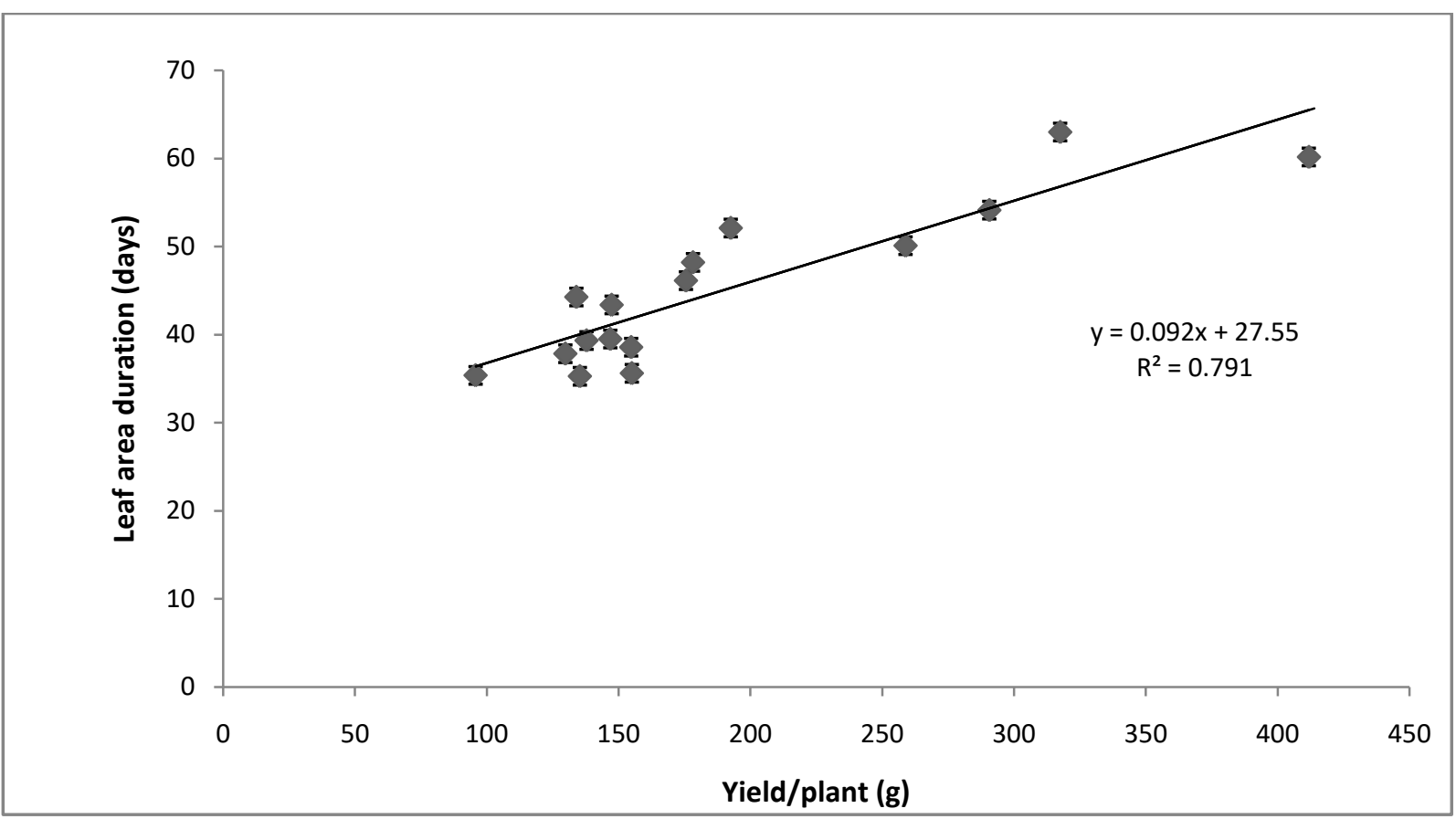

Figure 5 Scatter Plot of Correlation between leaf area duration and yield/plant

\section{Acknowledgments}

The authors would like to thank the Directorate of Post Graduate Studies, Assam Agricultural University, Jorhat, Assam, India and Technology Mission (MM-I), for providing support and financial aid in conducting the $\mathrm{Ph} \mathrm{D}$. research work. We are also thanks to the National Initiative on Climate Resilient Agriculture (NICRA) for providing us the Carbon dioxide Temperature Gradient Tunnel facility for experimenting.

\section{Conflict Of Interest}

Authors would hereby like to declare that there is no conflict of interests that could possibly arise.

\section{References}

ACIA (2004) Arctic climate impact and assessment. Cambridge, UK: Cambridge University Press.

Arnone JA, Jaler JG, Sphen EM, Niklaus PA, Wells CE, Korner C (2000) Dynamics of root system in native grassland: effect of elevated atmospheric $\mathrm{CO}_{2}$. New Phytologist 147: $8555-8571$

Ashraf M, Hafeez M (2004) Thermotolerance of pearl millet and maize at early growth stages: Growth and nutrient relations. Biologia Plantarum 48: 81-86.
Bhattacharya A (2019) Effect of High-Temperature Stress on Crop Productivity. In: Effect of High Temperature on Crop Productivity and Metabolism of Macro Molecules, Pages 1-114 Academic Press. https://doi.org/10.1016/B978-0-12-817562-0.00001-X.

Bray S, Reid DM (2002) The effect of salinity and $\mathrm{CO}_{2}$ enrichment on the growth and anatomy of the second trifoliate leaf of Phaseolus vulgaris. Canadian Journal of Botany 80: 349-359.

Chen JM, Ju W, Ciais P (2019) Vegetation structural change since 1981 significantly enhanced the terrestrial carbon sink. Nature Communications: 4259. https://doi.org/10.1038/s41467-019-12257-8.

Das R (2003) Characterization of responses of Brassica cultivars to elevated $\mathrm{CO}_{2}$ under moisture stress condition. $\mathrm{Ph}$. D Thesis submitted to the Division of Plant Physiology, IARI, New Delhi.

Erickson AN, Markhart AH (2002) Flower developmental stage and organ sensitivity of bell pepper (Capsicum annuum L.) to elevated temperature. Plant, Cell and Environment 25: 123-130. https://doi.org/10.1046/j.0016-8025.2001.00807.x

Evans GC (1972) Quantitative Analysis of growth. Blackwell Scientific Publication Oxford, London.

Ferris R, Sabatti M, Miglirtta F, Mills RF, Taylor G (2001) Leaf area is stimulated in Populus by free air $\mathrm{CO}_{2}$ enrichment (POPFACE), through increased cell expansion and production. 


\section{0}

Das et al.

Plant Cell \& Environment 24: 305-315. Purkyastha J, Alam SI, Gogoi HK, Singh L, Veer V (2012). https://doi.org/10.1046/j.1365-3040.2001.00684.x.

Molecular characterization of 'Bhut Jolokia' the hottest chilli .

Ge ZM, Zhou X, Kellomaki S, Zhang C, Peltola H, Wang KY (2012) Acclimation of photosynthesis in a boreal grass (Phalaris arundinaceae L.) under different temperature, $\mathrm{CO}_{2}$ and soil water regime. Photosynthetic 50 (1):141-151. doi: 10.1007/s 11099-0120014-x.

Guinness Book of World Records (2006) Hottest Spice. Available on www.guinnessworldrecords.com, accessed 13 Sept. 2006.

IPCC (2014) Climate Change 2014: Mitigation of Climate Change. In: Edenhofer OR, Pichs-Madruga Y, Sokona E, Farahani S, Kadner K, Seyboth A, et al. (Eds.) Contribution of Working Group III to the Fifth Assessment Report of the Intergovernmental Panel on Climate Change, Cambridge: Cambridge University Press.

Jumrani K, Bhatia VS, Pandey GP (2017) Impact of Elevated Temperatures on Specific Leaf Weight, Stomatal Density, Photosynthesis and Chlorophyll Fluorescence in Soybean. Photosynthetic Research 131 (3): 333:350. doi: 10.1007/s11120016-0326-y.

Li Q, Lu X, Wang Y, Huang X, Cox PM, Luo Y (2018) Leaf area index identified as a major source of variability in modeled $\mathrm{CO}_{2}$ fertilization. Biogeosciences 15: 6909-6925. https://doi.org/10.5194/bg-15-6909-2018, 2018.

Liu SR, Barton C, Lee H, Jarvis PG, Durrant D, Jiang ZH, Centritto M, Liu SR, Chiatante D (2002) Long-term response of Sitka spruce (Picea sitchensis (Bong.) Carr.) to $\mathrm{CO}_{2}$ enrichment and nitrogen supply. I. Growth, biomass allocation and physiology. Plant Biosystems, 136: 189-198.

Mailliard P, Guehl J, Muller J, Gros P (2001) Interactive effect of elevated $\mathrm{CO}_{2}$ concentration and nitrogen supply on partitioning of newly fixed ${ }^{13} \mathrm{C}$ and ${ }^{15} \mathrm{C}$ between shoots and roots of pedunculate oak seedling (Quercus robur). Tree Physiology 21: 163-172.

Petty GW (2004) A First Course in Atmospheric Radiation. Sundog Publishing, Pp. 229-251.

Power JF, Willis WO, Grunes DL, Reichman GA (1967) Effect of soil temperature, phosphorus and plant age on growth analysis of barley. Agronomy Journal 59: 231-234.

Rudrapal M, Sarwa KK (2020) Capsicum: Chemistry and medicinal properties of indigenous Indian varieties. Intech open, DOI: 10.5772/intechopen.92241M Published May 28th 2020.

Runion GB, Finegan HM, Prior SA (2011) Effects of Elevated Atmospheric $\mathrm{CO} 2$ on Non-native Plants: Comparison of Two Important Southeastern Ornamentals. Environmental Control in Biology 49:107-117 DOI: 10.2525/ecb.49.107.

Sharma N, Sinha PG, Bhatnagar AK (2014) Effect of elevated $\left[\mathrm{CO}_{2}\right]$ on cell structure and function in seed plants. Climate Change and Environmental Sustainability 2(2): 69-104.

Sirohi GS, Uprety DC, Tomar OPS (1978) Studies on root growth of wheat varieties. Indian Journal of Plant. Physiology 21: 185-196.

Solomon S, Qin D, Manning M, Chen Z, Marquis M (2007) Climate change 2007: the physical science basis. Contribution of Working Group I to the fourth assessment report of the Intergovernmental Panel on Climate Change. Cambridge, UK and New York, NY, USA: Cambridge University Press, Pp. 996.

Teng N, Wang J, Chen T, Wu X, Wang Y, Lin J (2006) Elevated $\mathrm{CO}_{2}$ induces physiological, biochemical and structural changes in leaves of Arabidopsis thaliana. New Phytologist, 172: 92-103.

Thinh NC, Kumagai E, Shimono H, Kawasaki M (2018) Effects of elevated atmospheric $\mathrm{CO}_{2}$ concentration on morphology of leaf blades in Chinese yam. Plant Production Science 21: 311-321. DOI: 10.1080/1343943X.2018.1511377.

Tiwari A, Kaushik MP, Pandey KS, Dangi RS (2005) Adaptability and production of hottest chili variety under Gwalior climatic conditions. Current Science 88(10): 1545-46.

Uddling J, Teclaw RM, Kubiske ME, Pregitzer KS, Ellsworth DS (2008) Sap flux in pure aspen and mixed aspen-birch forests exposed to elevated concentrations of carbon dioxide and ozone. Tree Physiology 28: 1231-1243 .

Van der Kooi CJ, Reichb M, Low M, De Kok LJ, Tausz M (2016). Growth and yield stimulation under elevated $\mathrm{CO}_{2}$ and drought: $\mathrm{A}$ meta-analysis on crops. Environmental and Experimental Botany 122:150-157. 